\title{
Analysis the Educational Factor of Graduate Students from a Bachelor's Degree in English as a Foreign Language
}

\author{
Ramirez Valencia Astrid ${ }^{1}$, Borja-Alarcón Isabel ${ }^{1} \&$ Ramirez Valencia Magnolia $^{2}$ \\ ${ }^{1}$ Universidad Distrital Francisco Jose de Caldas, Faculty of Science and Education, Bogotá, Colombia \\ ${ }^{2}$ Universidad Distrital Francisco Jose de Caldas, Faculty of Engineering, Bogotá, Colombia \\ Correspondence: Ramirez Valencia Astrid, Universidad Distrital Francisco Jose de Caldas, Faculty of Science \\ and Education, Bogotá, Colombia. E-mail: astramirez@gmail.com
}

\author{
Received: May 15, 2018 Accepted: June 5, 2018 Online Published: June 7, 2018 \\ doi: 10.5539/elt.v11n7p48 URL: http://doi.org/10.5539/elt.v11n7p48
}

\begin{abstract}
This article seeks to raise awareness about the impact of graduate students from an undergraduate English program at a public university, from 2011 to 2015, in the geographic scope field. Once they have completed their educational process, which emphasizes on English as a foreign language as well as on the pedagogical and research fields.

The main purpose of this paper is to analyze the impact of graduate students from an English teaching program to determine the possible weakness or strengthens that let us consider some modifications in the curriculum that currently educates future teachers.

To achieve this purpose, it was necessary to establish a study of these future teachers. As a consequence, an analysis was carried out on the data collected by using interviews, applied to the population.

This study showed the high level of employability achieved by the students from the Bachelor's degree in English, once they finished their studies. It was also observed, that there was a low occupancy in the research field, regardless of being one of the emphases of the curriculum offered by this academic program.

Despite this achievement, it is necessary to ask about the perception of employers on the graduates and their employability, as well as the effectiveness of their learning process and their level of performance in the educational field, as a global teacher.
\end{abstract}

Keywords: graduates, competence, academic training, satisfaction

\section{Introduction}

In the present era, it is necessary to reflect on the training processes followed by programs that train students on how to be an English teacher; these processes are better justified by the high-quality conditions necessary to acquire accreditation, to which all universities from our country must be submitted.

Taking into account these considerations, it is necessary to study the scope and goals achieved by these programs, with the purpose of measuring the impact of its graduates in the labor field.

To that end, a series of guidelines were developed, which take into account factors studied by the graduate students. Based on these reflections, it is important to analyze and study this group of people, looking at the employment profile developed within its curriculum.

The following article presents the findings from a study developed with this kind of population, within a Bachelor's degree program for English teachers. Which has, as its fundamental purpose, training principles for being teachers as researchers, reasons why the employment profile was studied in relation to the curriculum offered in this academic program.

This article is developed in four parts: the first part introduces theoretical elements related to the graduate students and its follow-up process. Follow by an explanation of the instruments used to collect the information related to the study of the graduate teachers. The third one presents the analysis of the collected information, including a description of the studied population. Finally, the fourth one presents the conclusions and recommendations of the study, as well as the possible topics to be analyzed in future research studies. 


\section{Theoretical Framework}

Here are some concepts that were taken into account for the development of the present document.

\subsection{Graduates}

Many entities have tried to study the graduate population. Among the most distinguished, we have the Ministry of National Education (MEN) (2012), which establishes a difference between the word graduate and undergraduate, determining that the first one is the student who completes its plan of studies, while the second one is related with the student who has met the requirements of a university entity, and therefore; it is ready to receive a degree.

But, we have the perspective of the Association Columbus (2012), for whom the graduate is the presentation of a University through which society can identify and assess the quality of the academic training in an institution, the result of this is the recognition given to the graduate students that have had a training education that is shown in the performance associated with the action field that is developed in the labor market.

Finally, the Jorge Tadeo Lozano University (2012) thinks out the graduates as a source of knowledge that allows determining improvement plans within the curriculum by offering some guidelines to be applied in the academic programs from an institution.

Here, it is stated the importance of establishing a relationship between the University and the graduate students, where their professional experiences are shared, while the University based on this relationship, can identify shortcomings with the purpose of addressing some implementation and improvement plans within the programs offered to their students.

Taking into account these perspectives, we find the following conditions: The first one deals with the graduate as a product, that is to say, it is the result of a person who has completed a plan of studies, while the second perspective deals with the graduates as a result, because it is the way in which the university can be considered as a particular social group. In the third vision, the graduate is though as a projection that provides information with which an institution can make actions of improvement within the curriculum offered to students who are enrolled in different study programs.

It is interesting to acknowledge how all of them raise the need for analyzing the graduate students, even having different views about the student who has completed a plan of studies. That is to say, this person can provide information that is relevant and valuable to educational institutions, especially at the university level.

In this sense, the need arises to carry out studies, tracking, and analysis to graduates, for the relevance of the information offered to institutions where this person received training. From this point forward, some parameters will be established in relation to the follow-up process defined for the graduates.

At the same time, García (2010) and Flores (2012) state that, during the accompaniment to the graduate students, it is necessary that the institutions validate their processes of teaching, with the purpose of examing the professional development and the living conditions of the graduate students over a period of time.

\subsection{Monitoring the Graduate Students}

Again, it is necessary to study the visions made by institutions recognized within the university environment, that had developed a different process of accompaniment that must be made to the students who have completed their plans of studies, which are expected to be contracted for any school or educational institution.

On the one hand, the National Pedagogical University from the State of Chihuahua, Mexico (2014) determined that the following up process of the graduate is a source of investigation and evaluation of the academic programs carried out by universities that study the performance of their professionals.

In addition, Flores (2012) explained that the studies about the graduates could be taken as a source of information on the institution quality. Therefore, their experiences should be analyzed after they have received the title, from an educational institution itself.

Aguilar (2014) establishes a relationship between the monitoring of the graduate, the occupancy rate and the quality of the institution, based on the ability for finding an employment, which shall be identified by the first element mentioned above. In this way, the highest degree of the employment is related to the highest level of university quality.

So, the National Pedagogical University of the State of Chihuahua (2011) shows how to follow up the process to the graduate by demonstrating its impact on researching and evaluating studies, especially in those aspects associated to studies related to graduate students. 
Aguilar (2014) raises the question about how the approaches to the graduate students can define improvement plans within the universities; as a result, it shall be defined by taking into account a projection of aspects found through the study of the graduate students. Starting from this point, there is a need for an evaluation plan at university institutions based on these studies.

To make the monitoring of the graduate students, Lopez (2004) and Gasparini y others (2001) think about studying their educational preparation.

Based on these points of view, an educational factor of graduates from the bachelor's degree in English will be addressed in detail.

\subsection{The Educational Factor}

In accordance with the MEN, education of the human being is conceived as a fundamental condition and a priority for the social and economic development of the country, in addition to being a universal right that strengthens the construction of justice and democratic societies.

Currently, we have implemented a number of educational reforms that seek to respond to the needs of our society to achieve a higher economic and social development level.

To achieve this purpose, the Educational Development Plan proposed by MEN has been conceived, taking into account three guideline considerations: Coverage, quality, and efficiency.

\section{Methodology}

This section describes the methodological procedure used to carry out this investigation. It explains the activities included in this process, illustrated in Figure 1.

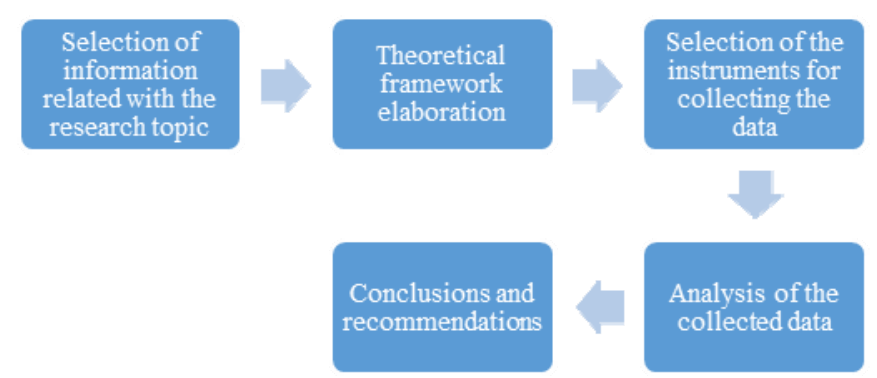

Chart 1. Diagram of the overall process of investigation. Source: own elaboration

Once a qualitative approach was adopted, a survey was designed and applied to the population, whose data was analyzed, based on the theoretical foundations embodied in this study, to respond to the objectives stated in this research. Such information, related to the English teachers' education, served to develop and restructure the functions and goals of an academic program that trains these professionals.

This research project was developed in the following five stages, which are being illustrated in Table 1.

Table 1. Stages of the research process of this study. Source: own elaboration

\begin{tabular}{ll}
\hline Phase & Processes \\
\hline First stage & Search for information from different sources. \\
Second stage & Construction of the theoretical framework. \\
& Analysis of the research instruments. \\
Third stage & Selection of the instruments. \\
Fourth stage & Data analysis. \\
Fifth stage & Conclusions and recommendations. \\
\hline
\end{tabular}

As it is evident, this study has a descriptive and interpretive nature, taking a critical perspective from the researcher, based on the foundations included in the theoretical framework, which is expected to have strong 
argumentations that will allow to make a following up studies of the English teachers program, to make some suggestions, that can be considered in the curriculum that educates these professionals.

Now, the tools and techniques of data collection included in this research will be explained. It is necessary to explain that this information was collecting during more than one year, during this time, it was necessary to localize the graduate students, to ask them to answer the included instruments used in this study.

Many times, it was not easy as we imagined localizing the graduate students, mainly because the university does not have true and real information about them, so we decide to localize them by our contacts and sources.

\subsection{Interviews}

To begin with, it is necessary to take into account the discussion that Buendía (2002) make on these instruments, specifying that they allow knowing the views of the people orally and writing, with or without the presence of the interviewer.

In the same way, Corbetta, P. (2007) adds that in this kind of instrument, the producer of the artifact must propose questions, that are easy to understand for anyone who responds.

In this sense, the following delibarations were taken into account: First, the number of questions was examined, and it was established that they should not be extensive, in order not to strain the participants.

For this situation, the questions were closed, but they always included the question of Why? With the purpose of having more information related to the questions included.

But, there was a particular care with the word order of the questions, always seeking to be presented intelligible and neutrally, avoiding inducing the participant to give a response on the part of the interviewer.

Once the researcher analyzed all these considerations, it was proceeded to gather information about the graduates through the implementation of the instruments previously explained.

To achieve this purpose, some meetings were organized where graduate teachers also had the opportunity to talk about their professional development experiences.

\subsection{Population}

The participants included in this study were 80 graduate students of an English degree program from 2011 to 2015.

For achieving the goal of this research, it was included a sample of 80 students, graduate from 2011 to 2015 that was just a short sample, this number of population was taken for being easy to figure out.

They are a group of students from a public university in which they have studied to be an English teacher.

\section{Analysis of the Results}

In this section, the results obtained from the collected data are presented. This information is related to the competence they have by analyzing their strengths and weaknesses.

\subsection{Competences}

Now, the results related to other aspects included in the survey are going to be presented. In all of them, the students` opinions are going to consider taking into account their points of view.

First, it was studied the speaking, listening, reading and writing skills showing students competence in those abilities. After that, it was asked if they have presented any international test asking how was the results.

Finally, students talk about their weakness related to the English language based on their opinions related with the competence field.

We will begin with the analysis of the data related to the language level by showing their competence in the four language skills (writing, reading, speaking and listening) because they are the most common language skill studied.

\subsection{Speaking Competence}

Table 2 and Figure 2 show the data related to oral production. It was asked about their speaking ability considering three levels: advance, intermediate, and beginners. Here, you have the results. 
Table 2. Competence in oral production. Source: own elaboration

\begin{tabular}{llll}
\hline Ability Level & Advanced & Intermediate & Beginners \\
\hline Speaking \% & $55 \%$ & $25 \%$ & $10 \%$ \\
\hline
\end{tabular}

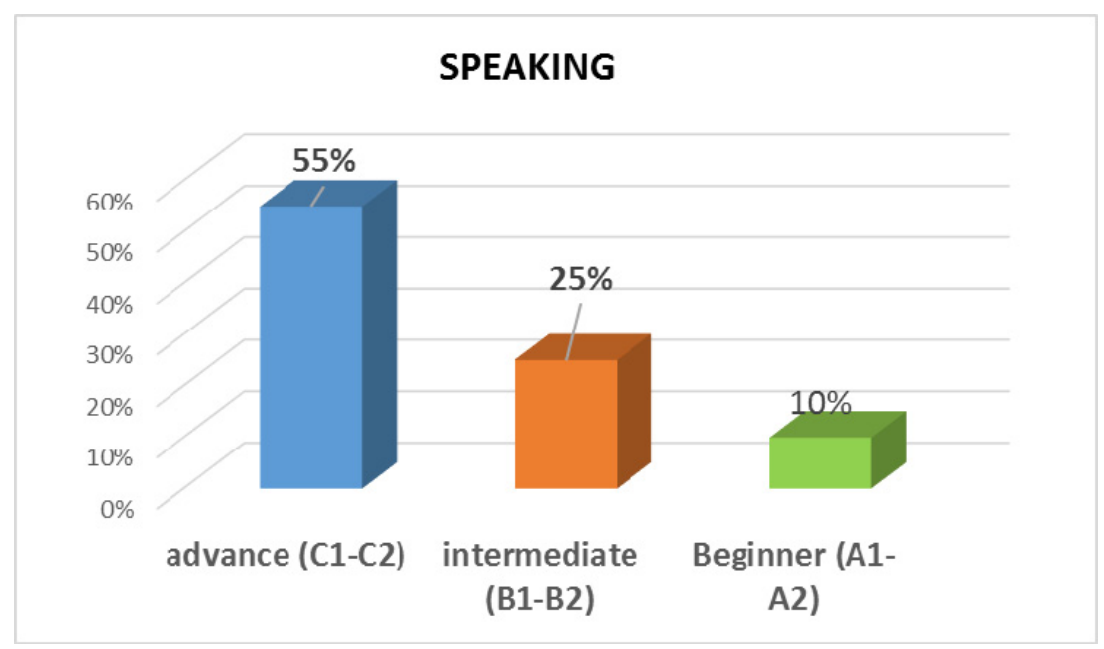

Chart 2. Competence in oral production. Source: own elaboration

In regarding of this skill, students claimed to have an advance competence represented by their capacity to generate statements with form and function according to the context where the foreign language is used. This involves tone, intention, and speed of the voice.

In this sense, the most important thing is to be able to communicate properly, when it is considered indispensable, in such a way that the language is a means of contact and interaction with the other speakers, without showing inhibitions, or mistakes in the usage of language, without any interruption specially when they are involved in a group of people where they can demonstrate their capacity to use the language.

However; taking into account the medium and low level results, it was found that $35 \%$ of the sample expresses that their language level was not good. Here, it will be necessary to consider the possible causes for bringing this information. Authors such as Cahyono, and others (2011) and Richards (2008) determine that this is probably due to a number of reasons.

The first one is related to the linguistic aspects, in which case the speaker can talk slowly, paused, using crutches, spending enough time in organizing ideas, using uncompleted sentences, for example, they present ideas in an inconsistent and disorganized way, making grammatical errors, using inadequate intonation and pronunciation for many reasons.

Thus, it is also important to consider that there some psychological factors that do not let students speak fluently. Tavakoli and Others (2015) explains that "In many cases, people do not speak for the fear of making mistakes, especially when they have to speak in a classroom. For instance, they are afraid to speak in front of their peers or their teachers" (p. 75). For this reason, it is necessary that the teacher creates a different atmosphere in the classroom, pointing out that, if the students make mistakes, avoiding comments, rejections or negative attitudes from their classmates.

That would make them feel inhibited to speak. In this regard, Bauman, Z. (2013) explains that occasionally, some people may feel panic to speak in certain moments, within a familiar language context use, so teachers must create a relaxed atmosphere, that make feel comfortable when they are speaking.

\subsection{Ability to Listen}

Table 3 and figure 3 show the listening ability according to the graduate English language students. Level of the graduates in relation to the oral comprehension, that is to say, to listen. 
Table 3. Competence in oral comprehension. Source: own elaboration

\begin{tabular}{llll}
\hline Ability & advance & intermediate & beginners \\
\hline Listen & $70 \%$ & $25 \%$ & $5 \%$ \\
\hline
\end{tabular}

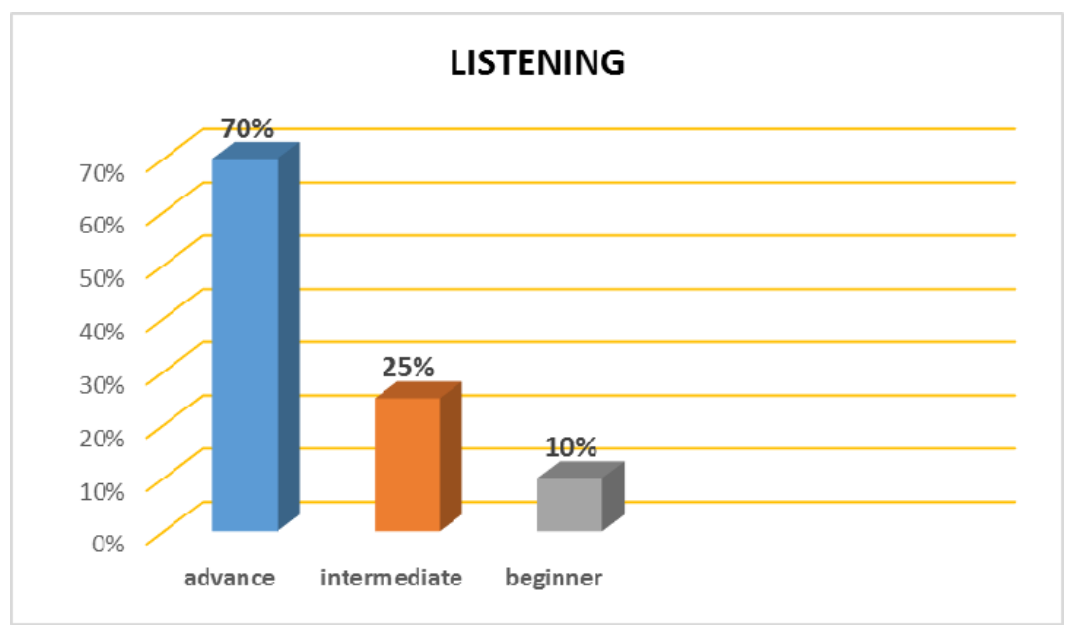

Chart 3. Competition in the ability to listen. Source: own elaboration

Yavuz, F (2017) views the listening skill as one of the most important factors for understanding the information, identifying relevant details in a conversation that let us leave aside those details that do not need to grasp the meaning from a message that is heard.

That is to say, analyzing this perspective, it can be inferred that the ability to hear has a lot of implications, which are not only related with what is heard, instead, it is associated with the intention and the cultural factors from the listener by estimating an advanced listening level ability.

In this sense, if the $70 \%$ of respondents said they have an advanced level, this means that they possess an adequate command in the field connected to the comprehension of a foreign language. Therefore; they can understand the foreign language.

\subsection{Ability to Read}

Calet N., Defior S., and others (2015) state that Comprehension requires a psico-linguistics, grammar interpretation knowledge for demonstatind that any person possesses this competence. But it is necessary to be aware that this ability has other different requirements that are related to the literature field, for example. So, it cannot be as easy as it seems to be.

Calet N., Defior S., and others (2015) explain too that reading requires a long and structured process, which carries learning and practicing of all the components related with the reading process separately" (p. 76).

Table 4 and Figure 4 illustrate the data related to the reading proficiency of the graduates' population.

Table 4. Competence in understanding

\begin{tabular}{llll}
\hline Ability & Advance(B1-B2) & Intermediate (B1-B2) & Beginners (A1-A2) \\
\hline Reading & $52 \%$ & $36 \%$ & $12 \%$ \\
\hline
\end{tabular}




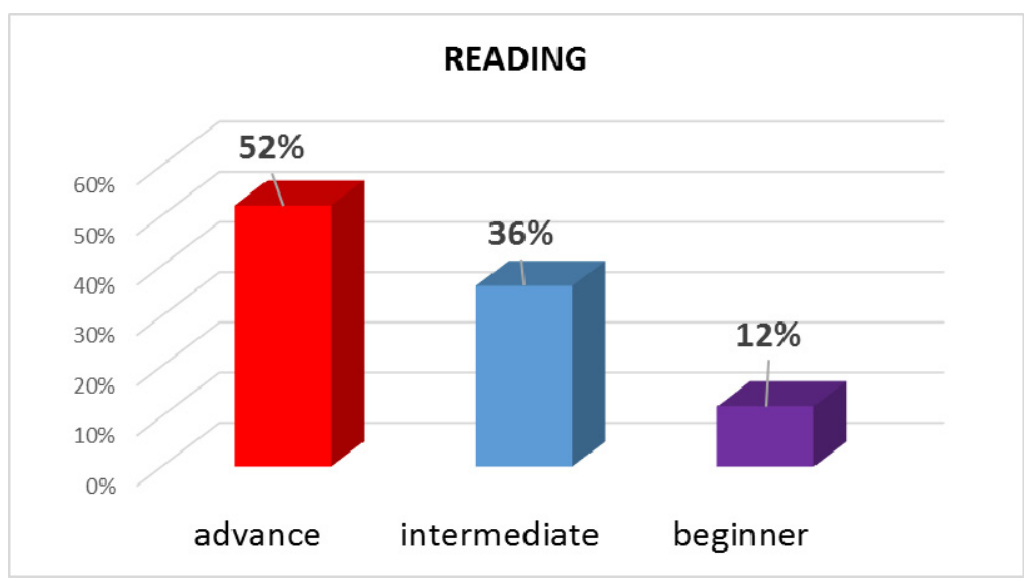

Chart 4. Skills in reading comprehension. Source: own elaboration

Based on the data, $52 \%$ of the interviewees state that they have reached a satisfactory reading competence. They have probably been trained in reading strategies; they let them possess enough language knowledge, allowing them to be able to read any kind of text.

\subsection{Ability to Write}

Finally, the Table 11 and Figure 13 illustrate the ability of graduates in relation to the written production.

Table 5. Competence in written production. Source: own elaboration

\begin{tabular}{llll}
\hline Ability & High (B1-B2) & East (B1-B2) & Under (A1-A2 \\
\hline Write & $53 \%$ & $38 \%$ & $9 \%$ \\
\hline
\end{tabular}

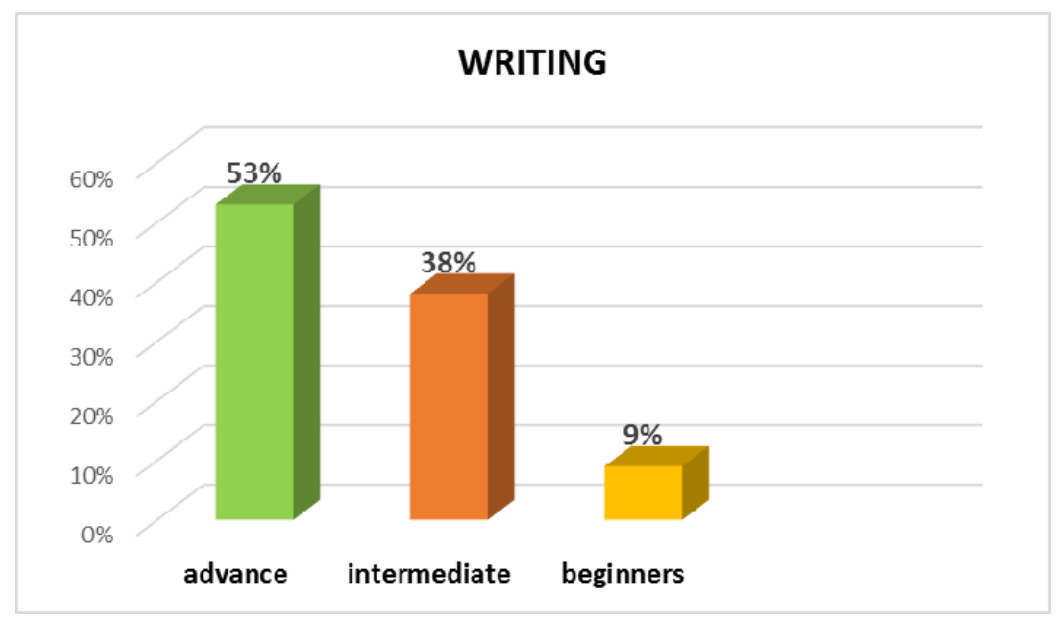

Chart 5. Competence in written production. Source: own elaboration

In response to the information recorded in this table, a high percentage of graduates is at a high level of competence in writing, which is a good indication, especially, by the importance that this has in the management of a foreign language.

Lindsay, C., and Others (2006) explain that "writing in a language is as important as talking, because through it, you can set different points of view on the part of who is writing. In addition, it requires a process and, as such, it has a few requirements" (p. 291).

For this reason, the majority of plans of study that are professionals including the subject of English must take into account the development of this ability, which is a central axis within the subjects offered to educate them. 
In summary, this skill is of utmost importance, especially for those students who are trained to be teachers, who, as suggested, it is not enough to devote himself to correct the vocabulary, grammar when writing; it is necessary to consider the structure of the text, consistency, the intention and, above all, they must form a critical and investigative spirit on the part of future teachers.

\section{Conclusions and Recommendations}

This research found that in the English language level of the graduate students is measured by their foreign language competence, in the knowledge that students possessed about the English language.

Although that a few numbers of participants stated that they have an advanced level in the four skills competence, it is undeniable that this condition should allow them to have a good job because many institutions have this criterion as a requirement for hiring teachers.

On the other hand, it confirms the need to implement an international test to assess the level of English language competence of future teachers, in order to establish this exam as a requirement for being graduate from English programs that teach students to be English teachers.

Finally, it is hoped that this study opens the door of some new research project related to the graduate students from English program by studying for example, their training, as well as their role in the schools in Bogotá city, too.

This invitation ought to be based on the findings and considerations that have been demonstrated in this project and paper because it is very important to continue thinking about the teacher's training process and the knowledge that they possess about the English language.

\section{References}

Aguilar (2014). Desafios laborales que enfrentan las egresadas de la licenciatura en administración agro tecnológica: caso facultad de ciencias agro tecnológicas de la universidad autónoma de chihuahua. Revista Mexicana de Agronegocios.

Bauman, Z. (2013). Liquid Fear. Oxford: Wiley.

Buendía, L. (2002). La observación científica en educación social y animación sociocultural, en López, F. y Pozo, T: Investigar en educación social. Consejería de Egresados

Cahyono, B. Y., \& Widiati, U. (2011). The Teaching of English as a Foreign Language in Indonesia. Malang: State University of Malang Press.

Calet N., Defior S., \& Gutiérrez-Palma N. (2015). A cross-sectional study of fluency and reading comprehension in Spanish primary school children. Res. Read. https://doi.org/10.1111/1467-9817.12019

Corbetta, P. (2007). Metodología y técnicas de investigación. Italia: McGrawHill.

egresados, estudio de caso y propuesta. Tesis inédita. Maestría en Investigación en Psicología Aplicada a la Educación. Universidad Veracruzana, Instituto de Psicología y Educación. Xalapa, Veracruz.

Flores, A. U. (2012). Seguimiento de egresados para la Licenciatura en Geografia. Generacion 1992. Red de Revistas Científicas de América Latina y el Caribe, España y Portugal, 86-87.

García, D. (2010). Satisfacción laboral. Una aproximación teórica. Revista CCCSS. Contribuciones a las Ciencias Sociales.

Gasparini, L. y otros. (2011). Educational Upgrading and Returns to Skills in Latin America: Evidence from a Supply-Demand Framework, 1990-2010. IZA Discussion Papers, 6244, Institute for the Study of Labor (IZA). https://doi.org/10.1596/1813-9450-5921

González Herrera, M. B., Figueroa González, E. G., \& Bustamante Curiel, J. A. (2013). Desempeño Profesional de los Egresados en Administración de una Institución de Educación Superior en México. Revista Internacional Administración y Finanzas, 6(5), 59-73.

Lindsay, C., \& Knight, P. (2006). Learning and Teaching English. Oxford: OUP.

López A. D. (2004a). Rumbo a la Acreditación: Seguimiento de

Maldonad, J. R. (2012). Programa Institucional de seguimiento de egresados Universidad Autónoma de Baja California Sur.

Ministerio de Educacion Nacional Decreto 2566 de 2003. (2003). MINISTERIO DE EDUCACION NACIONAL. [En línea] Disponible en: www.mineducacion.gov.co/1621/articles-104846_archivo_pdf.pdf [Recuperado el 
26 de nov. 2012].

Montes, M. (2010). Seguimiento de egresados de la licenciatura en la enseñanza del inglés desde la perspectiva de la dimensión formativa. Tesis de licenciatura inédita. Licenciatura en Enseñanza del Inglés. México. Universidad de Sonora.

Pagani, R. (2003). Agencia Nacional de Evaluación de Calidad y Acreditación. [En línea] Disponible en: http://www.uam.es7europea/glosario_convergencia_tuning.pdf [Recuperado el 01 de oct. de 2012]

Relación con la Universidad.: http://personal.globered.com/egresados/categoria.asp?idcat=20 Relaciones Institucionales. Sevilla.

Richards. (2008). Teaching Listening and Speaking. From theory to Practice. Cambridge University Press.

Ruiz R. y Green I (2003). II Curso-Taller Centroamericano sobre Metodología para Estudios de Seguimiento de Graduados Universitarios. Memoria. II Taller. Universidad de Buenos Aires. Facultad de Filosofía y Letras.

Tavakoli and Others (2015). Development of Speech Fluency Over a Short Period of Time: Effects of Pedagogic Intervention. TESOL Quaterly, 50(2).

Teichler, U. (2003). Aspectos metodológicos de la encuesta a graduados. En: Javier Vidal García (Coordinador). Métodos de análisis de la inserción laboral de los universitarios. Madrid: Consejo de Coordinación Universitaria.

Valenti, G., \& Varela, G. (2004). Diagnóstico sobre el estado actual de los estudios de egresados. México. ANUIES

Web, M. (2009). ¿Que son los estudiantes egresados? Relación con la Universidad. [En línea] Globered. Disponible en: http://personal.globered.com/egresados/categoria.asp?idcat=20 [Recuperado el 1 Oct. 2012].

Yavuz, F., \& Celik, O. (2017). The importance of listening in communication. Global Journal of Psychology. Research: New Trends and Issues.

\section{Copyrights}

Copyright for this article is retained by the author(s), with first publication rights granted to the journal.

This is an open-access article distributed under the terms and conditions of the Creative Commons Attribution license (http://creativecommons.org/licenses/by/4.0/). 